\title{
Features of Heavy Metals Accumulation in Bottom Sediments of the Southern Bug Hydroecosystem
}

\author{
Olena Mitryasova ${ }^{1}$, Piotr Koszelnik ${ }^{2 *}$, Renata Gruca-Rokosz ${ }^{2}$, Victor Smirnov ${ }^{1}$, \\ Svitlana Smirnova', Yevgen Bezsonov', Monika Zdeb², Sabina Ziembowicz ${ }^{2}$ \\ 1 Petro Mohyla Black Sea National University, Mykolaiv, Ukraine \\ 2 Rzeszow University of Technology, ul. Powstańców Warszawy 12, 35-959, Rzeszów, Poland \\ * Corresponding author's e-mail: pkoszel@prz.edu.pl
}

\begin{abstract}
The performed studies allowed determining the peculiarities of heavy metals accumulation in the sediments, as well as the nature of their distribution in the hydroecosystem Southern Bug (Ukraine). Geochemical anomalies are formed in the zones of influence of industrial and urban agglomerations. Technogenic pollutions of bottom sediments with heavy metals affects the qualitative state of the water environment and can cause cumulative toxicosis on the hydrobiont population in the zones of geochemical anomalies formation, namely in the area of influence of the Nova Odessa and Mykolaiv cities. The mechanism of the cumulative toxicosis emergence is accompanied by chronic effects of low concentrations on hydrobionts with an excess of permissible fluctuations on a regional background, which ultimately contributes to the development of intoxication.
\end{abstract}

Keywords: heavy metals, hydroecosystem, bottom sediments, concentration ratio.

\section{INTRODUCTION}

The development of territorial water resources management by a basin principle on the territory of Ukraine was implemented as a result of the Water Framework Directive. Determination of the geochemical characteristics of the bottom sediments within the river basins, namely the characteristics of the heavy metals distribution (HM) is of fundamental importance for ensuring the environmental sustainability of hydroecosystems. The rocks washed by river are potential natural sources of $\mathrm{HM}$ in the aquatic environment. Thus, $\mathrm{Mo}, \mathrm{Fe}, \mathrm{Mn}, \mathrm{Cu}, \mathrm{Zn}, \mathrm{Co}$ are always present in low concentrations in an aqueous environment. Among the anthropogenic sources of HMs, the greatest contribution is due to industrialization and urbanization (Pohrebennyk et al. 2019).

The research on the hydroecosystem of the bottom sediments reflects the features of the adjoining territories of the geochemical state, given the intensity and nature of human economic activity. The problem of HM accumulation is directly proportional to the issue of surface water contamination by heavy metals. The problem is most prominent in cities with developed infrastructure. That is why the bottom sediment is an indicator of the ecological state of hydroecosystems.

The behavior of HM in the hydroecosystem is due to the processes of sorption, sedimentation, solubility, boiling, diffusion, and so on. Each hydroecosystem seeks to achieve an equilibrium state (homeostasis), first of all, at the expense of self-healing, which is realized in two opposite directions. On the one hand, the hydroecosystem restores the pelagic environment (aqueous thickness) during the sedimentation of HM and its accumulation in the bottom sediments. The accumulation process and the toxic effect of HM in the hydrophobic deposits depend on many factors: their nature and physical and chemical properties, such as bottom sediments, temperature regimes, seasonal variations, oxidation-reducing conditions, the presence of suspended matter, the activity of the biotic component of the hydroecosystem, etc. The processes of HM sorption with 
suspended matter and deposition in benthal have been studied in detail for decades. Such a development results in loading on the bottom and benthos hydrobionts, since the toxic bottom sediment is a habitat for many classes of benthos and affects their species composition, as well as accumulation of the most dangerous substances in the food chain. It is known that benthophyte fish receive toxicants through the "water-bottom sedimentsbenthic invertebrates-fish" chain. Quite often, it is this development that erroneously provides the information about the status of water bodies without taking into account the levels of the bottom sediment pollution.

On the other hand, specific conditions (for example, dredging, time dynamics of $\mathrm{pH}$, mineralization, etc.), can induce secondary pollution due to the diffusion of HM into the water column. Under these conditions, the main load is felt by pelagic organisms.

Therefore, based on the information above, it is expedient to apply a comprehensive study on the state of the hydroecosystem. The latter is a very complex polyfunctional system, which is marked by superpositional interaction of a large number of factors in dynamic variations.

The importance of the spatial distribution of HM in the Ukrainian river water systems attracts the attention of many scientists. There are the largest variations of $\mathrm{Cd}, \mathrm{Cr}, \mathrm{Cu}, \mathrm{Hg}$ and $\mathrm{Zn}$ in the diocese of Oskil, Lopan, Udi and Siversky Donets in the territory of the Kharkiv, Donetsk and Luhansk regions (Vytavna et al. 2015). There is an interesting experience of the influence of sedimentary $\mathrm{Fe}$ and $\mathrm{Mn}$ on the oxygenation of overlying waters in dam reservoirs (Koszelnik and Bartoszek 2018).

The spatial distribution of chemical pollutants in the lateral and radial fluxes of the river systems of the rivers allows estimating the migration processes, identifying the sources of HM inflow, as well as the areas of their possible accumulation. Klymenko with co-authors (2016) found that in the modern period, the Ust river plays the role of an accumulator of anthropogenic products against the background of the geochemical anomalies of individual elements. Klebanov and Osadcha (2012), on the basis of data processing of the state network of hydrometeorological observations for the period 1990-2010, calculated the annual release of $\mathrm{Fe}, \mathrm{Zn}, \mathrm{Mn}, \mathrm{Cu}, \mathrm{Cr}$ from the Danube drainage basin and revealed the regularities of the quantitative ratio of the individual elements in the runoff of heavy metals. The influence of the South-Ukraine electric power producing complex on the ecological condition of the Southern Bug River is presented in work (Bezsonov et al. 2017). Andrusishin and Grubinko (2012), according to the results of the study on the seasonal dynamics of the metal content in water and the Zbruch river, it was found that the bottom sediments are characterized by excess of background indices for the content of $\mathrm{Zn}, \mathrm{Fe}, \mathrm{Pb}, \mathrm{Co}$, Ni and $\mathrm{Cd}$.

The Southern Bug River basin is an important part of the landscape, so its research has received sufficient attention, both in monitoring surveys at the level of oblast administrations and in the work of scientists. Thus, the monograph of Khilchevsky (2009) focuses on the components of the water balance of the Southern Bug River basin. It was noted that the annual rainfall in the lower part of the basin is from $470 \mathrm{~mm}$ to $540 \mathrm{~mm}$, since this area is in the steppe zone and is characterized by a small share of underground power and a small amount of rain floods. The average annual air humidity is $60-65 \%$. The rates of evaporation from the water surface are in the lower reaches - 800-900 mm. The Southern Bug River feeds at the expense of thawed waters during spring and winter periods and precipitation in the summer. The underground drainage on the basin is negligible. The mineralization of water is: spring flood $-600 \mathrm{mg} / \mathrm{dm}^{3}$; summer-autumn measurements $-674 \mathrm{mg} / \mathrm{dm}^{3}$.

Lyuta (2018) determined the patterns of distribution of chemical elements $(\mathrm{Pb}, \mathrm{Zn}, \mathrm{Cu}, \mathrm{Cr}$, $\mathrm{Ni}, \mathrm{Co}$ ) in the bottom sediments of river basins in the territory of Ukraine (including in the basin of the Southern Bug); they analyzed the spatial background regular distribution of their content in the bottom sediments from the north to the south, that is, from the river basins of the Polis zone to the basins of the Steppe landscape-climatic zone, which is in line with the geochemical features of the soil cover of the catchment areas. The author concluded that despite the prolonged and intensive man-made impact on the surface waters of Ukraine, the preponderance of natural factors in the formation of the chemical composition of the bottom sediments is a priority.

We directly conducted a study of the pollution of the bottom sediments of the Buhsky estuary, which formed below the course of the Southern Bug. In Mykolaiv, Southern Bug gradually passes into the Buhsky estuary, the water area of which rises to $2-3 \mathrm{~km}$, and the maximum depth 
in the lower reaches reaches 5-6 m. In the work (Smyrnov and Smyrnova 2014), a GIS-oriented system approach for creating digital cartographic models of HM pollution of the bottom sediments was introduced to determine their ecological quality on the example of the Buhsky estuary. The man-caused anomalous zones of high HM content $(\mathrm{Zn}, \mathrm{Ni}, \mathrm{Mn}, \mathrm{Pb}, \mathrm{Cu})$ in the bottom sediments are identified with the zones of influence of industrial enterprises.

The aim of the work was to determine the spatial distribution of heavy metals in the bottom sediments of the hydro ecosystem Southern Bug on the site of the city of Nova Odessa - the city of Mykolaiv. The research tasks included: 1) estimating the level of contamination by the heavy metals (Cr, Ni, Cu, Zn, Mn, Fe, Sr) of the bottom sediments of the Southern Bug on the geochemical background; 2) determining the features of accumulation of heavy metals in the bottom sediments; 3) indicating possible risks for hydrobionts (based on the literature data).

\section{MATERIALS AND METHODS}

The strategy of testing the bottom sediments was based on the following principles:

- The location of the bottom sediments sampling stations along the flow of the hydroelectric system Southern Bug with a step of 5-10 km, taking into account the river morphology and location of settlements with maximum approximation to the regular according to the "Requirements for ecological and geological research at a scale of 1:50 000-1:25000" (Ostrovsky and Ostrovsky 1998).

- The usage of sampling equipment (bathometer, bottom ladle Morduhay-Boltovsk area of capture $1 / 40 \mathrm{~m}^{2}$ by RD 52.24.609-2013 (Organizing and Conducting Observations on the Content of Pollutants in the Bottom Sediments of Water Bodies) (Fig. 1).

- The sampling of bottom sediments was conducted during the summer of 2018 (summer data cut). The samples were collected with the help of a rod dipper.

- The samples were carefully mixed and dried at a temperature not higher than $40 \pm 5^{\circ} \mathrm{C}$, carefully mixed, quartile. Immediately before the analysis, the sample was ground in a mortar and sifted through a sieve with mesh size of $1 \mathrm{~mm}$.
In order to determine the gross content of HMs ( $\mathrm{Mn}, \mathrm{Cu}, \mathrm{Zn}, \mathrm{Ni}, \mathrm{Cr}, \mathrm{Sr}, \mathrm{Fe}$ ), the studied samples were processed concentrated nitric acid in the ratio solid and liquid phase 1:5 with heating and periodic stirring for day. The concentrations of elements in the samples were determined using $\mathrm{X}$-ray spectrometry using S2 PICOFOX Bruker X-ray spectrometer - detector type: silicon drift detector, high voltage generator: MNX 50P50/XCC, $\mathrm{X}$-ray source: MCB50 air-cooled metal ceramic $-0.7 \mathrm{G}, \mathrm{X}$-ray optics: multilayer monochromator. The statistical processing of the experimental data was performed using the Microsoft Excel and Statistica 10.0 software package.

The characteristics of the heavy metal content were conducted according to indicators: $\mathrm{C}_{\mathrm{i} \text {, av }}$ - the average value is concealed in the studied areas, $\mathrm{C}_{\mathrm{i}, \min }$ is the minimum concentration of $\mathrm{HM}, \mathrm{C}_{\mathrm{i}, \max }-\mathrm{m}_{\mathrm{imin}}$ maximum concentration of HM. The calculations of these parameters were carried out according to the formulas (table 1):

$$
C_{i, a v}=\Sigma \frac{C_{i}}{n}
$$

where: $C_{i}-$ metal content in the i-bottom sample deposits selected in item $n$.

The content of heavy metals in the bottom sediments in Ukraine is not normalized. Therefore, the estimation of the level of chemical contamination of the bottom sediments is carried out in accordance with the parameters $\mathrm{K}_{c}$, developed in conjunction with geochemical and geohygienic studies of the natural environment. The coefficient of concentration of a chemical substance $\left(\mathrm{K}_{\mathrm{c}}\right)$ is determined by the ratio of the actual content in the soil $\left(\mathrm{C}_{\mathrm{i}}\right)$ in $\mathrm{mg} / \mathrm{kg}$ to the regional background content of the $\mathrm{HM}\left(\mathrm{C}_{\phi \mathrm{i}}\right)$ :

$$
K_{c}=\frac{C_{i}}{C_{\phi i}}
$$

\section{RESULTS AND DISCUSSION}

The research was conducted at the bottom of the Southern Bug hydroecosystem on the section between the settlements of Mykolaiv and Nova Odesa. The hydroecosystem of the Southern Bug is located mainly in the area of the Ukrainian crystalline shield and only its lower current with the largest influx of Ingul lies within the Black Sea lowlands. In the upper part of the basin, 


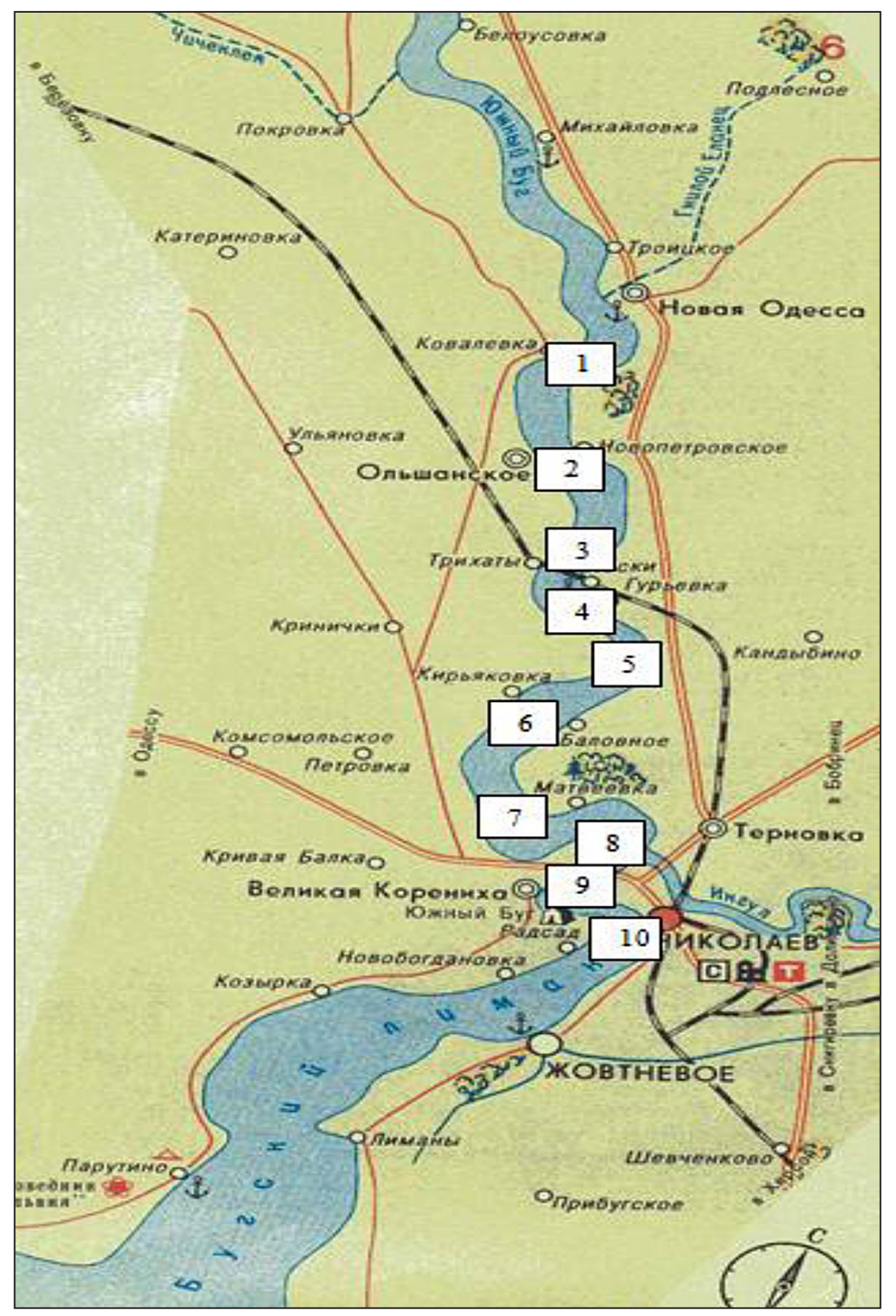

Fig. 1. Locations of the sites of sampling of the bottom sediments at the Southern Bug River; SBS 1 - v. Kovalivka, SBS 2 - v. Trikhati, SBS 3 - v. Olshanske, SBS 4 - v. Gurievka,

SBS_5- v. Constantinovka, SBS_6 - v. Kiryakovka, SBS_7 - v. Nadbuzske (sources), SBS_8 - Varvarovka, SBS_9 - Mykolaiv River Port, SBS_10 - Mykolaiv Sea Port

crystalline rocks lie close to the surface, sometimes going out to the surface in the valley of the river. The South Bug River flows into the Black Sea, forming together with the Dnipro the Dnipro-Bug estuary. A powerful source of HM in the reservoir is the inadequately treated wastewater of industrial enterprises that contains a significant amount of chemical elements. In reservoirs of HM mainly sorbed by suspended substances and in the form of sorbed conglomerate are deposited and form stable geochemical anomalies for decades (Trakhtenberg et al. 1994).

Among HM, Cr, Zn, Ni, Cu, Mn, Fe, Sr have the greatest ecological significance. The choice of these elements is due to the factors of their influence on hydrobionts. Hydrobionts react to the pollution of the hydroecosystem by various functional disorders, which are clearly manifested in the long-term exposure of the element to the organism. In any case, the balance of microelements or the change in their ratio in the organism of hydrobionts leads to pathological physiological or functional states.

Almost all hydrobionts, both plant and animal organisms, can accumulate toxic substances for a long time. In fish, heavy metals can be deposited in the skin, bones, muscles and gills. In mollusks, toxicants accumulate in the mantle cavity, in the leg and hepatopancreas, some in the muscles. In higher aquatic vegetation, the deposition of many poisons is observed in the root (Dudnyk 2014). 


\section{Elements of the I class of danger}

Chrome (Cr) is a chemical element of the VI-B subgroup of the periodic system elements with atomic number 24 . This is a heavy metal with an atomic weight 51.996 which is contained in the Earth's crust $(0.03 \%)$ and sea water $\left(0.05-0.5 \mathrm{mg} / \mathrm{dm}^{3}\right)$ (Dritsa 1985).

The chrome content at the investigated area ranged from 16.1 to $113.5 \mathrm{mg} / \mathrm{kg}$, the average value was $42.7 \mathrm{mg} / \mathrm{kg}$ (Table 1). The concentration coefficient $\mathrm{K}_{\mathrm{c}}$ was determined relative to the regional background of bottom sediments $(40 \mathrm{mg} / \mathrm{kg})$. The average rate was 1.07 (0.4-2.84). The variation element ranged from 16.1 to $32.9 \mathrm{mg} / \mathrm{kg}$ (SBS_1-SBS_7) corresponding with fluctuations indicator $\mathrm{K}_{\mathrm{c}}$ from 0.4 to 0.82 . Within the limits of the influence of the Mykolayiv industrial and urban agglomeration (SBS_8-SBS_10) there was an abnormally high content of chrome in the bottom sediments from 73.8 to $113.5 \mathrm{mg} / \mathrm{kg}$. In terms of $\mathrm{K}_{\mathrm{c},}$ the range varied from 1.84 to 2.84 (Table 1, Fig. 2a).

The toxicity of $\mathrm{Cr}$ varies and depends on the degree of oxidation. The compounds of $\mathrm{Cr}(\mathrm{VI})$ are 100-1000 times more toxic than those of $\mathrm{Cr}$ (III). The physiological need for hydrobionts $\mathrm{Cr}(\mathrm{III})$ is proven: it is part of the glucose tolerance complex (GTF), which regulates the metabolism of glucose in living organisms (Snitinsky et al. 1999, Vincent 2000, Myslyva 2016).

Zinc ( $\mathrm{Zn}$ ) The average zinc content in the Earth's crust is $8.3 \cdot 10^{-3} \%$ (15). Its content in the bottom sediments depends from the parent rock, the content of organic matter and the $\mathrm{pH}$ reaction of the soil solution. This element is an intensive migrant both in surface and underground waters. The geochemically active sorbent of zinc in the natural environment is clay, and the main reservoir is hydrogen sulfide.

The averaged zinc content was $38.2 \mathrm{mg} / \mathrm{kg}$ with a variation within the range from 22.2 to
$72.5 \mathrm{mg} / \mathrm{kg}$. The background regional content of zinc was $40 \mathrm{mg} / \mathrm{kg}$ (Luta 2018). Accordingly, the concentration coefficients were $0.55-1.81$ with an average of 0.95 . The area v. Kovalovka - v. Nadbuzke (SBS_1-SBS_7) there is a regional background level $22.2-44.0 \mathrm{mg} / \mathrm{kg}$, which corresponds $\mathrm{K}_{\mathrm{c}}$ within the range from 0.55 to1.1. Almost twice as high content of the zinc $(72.5 \mathrm{mg} / \mathrm{kg})$ relative to the regional background was observed near Mykolaiv (Table 1, Fig. 2b).

The values of the $\mathrm{K}_{\mathrm{c}}(1.15-1.81)$ on the stations near Sea Port (SBS_8-SBS_10) indicate the formation of geochemical anomalies, which in some way will further influence the hydrobionts. The research results (Pinkina 2006) indicate that the phenomenon of mollusks' adaptation to the excess concentrations of $\mathrm{Zn}^{2+}$ is expressed in the increased resistance ones to highly toxic metals, which at "chronic" concentrations is replaced by the phase of depression due to the violation of their adaptive mechanisms.

\section{Elements of the II class of danger}

Nickel (Ni) is a scattered element of the biosphere. Its average content in soils is $4.0 \cdot 10^{-3} \%$, in natural surface waters $-3.4 \cdot 10^{-7} \%$ (Dritsa 1985 ).

The average concentration of $\mathrm{Ni}$ in the bottom sediments was $9.5 \mathrm{mg} / \mathrm{kg}$, which is half the value of the regional background $(20 \mathrm{mg} / \mathrm{kg})$. The spatial diversity of nickel for the investigated area ranged from 7.3 to 12.7 . The concentration coefficient was defined at the level of $0.36-0.63$ with an average value 0.47 (Fig. 2c).

There was peak magnification of the Ni content in Mykolaiv of about $12 \mathrm{mg} / \mathrm{kg}$, in particular near Varvarivka district, River and Sea ports. Another increase of concentration up to 12.5 occurred in Kovalivka, which is located below the city of Nova Odesa. Studies (Bandman et al. 1989) confirm that the increase of the nickel content in the river water can be observed in the places that

Table 1. Statistical characteristics of bottom sediments about the heavy metals content in the Southern Bug

\begin{tabular}{|c|c|c|c|c|c|c|c|}
\hline & \multicolumn{7}{|c|}{ Danger class (Dmitriev et al. 1989) } \\
\hline & \multicolumn{2}{|c|}{ I } & \multicolumn{2}{|c|}{ II } & \multicolumn{3}{|c|}{ III } \\
\hline Metal & $\begin{array}{c}\mathrm{Cr} \\
{[\mathrm{mg} / \mathrm{kg}]}\end{array}$ & $\begin{array}{c}\mathrm{Zn} \\
{[\mathrm{mg} / \mathrm{kg}]}\end{array}$ & $\begin{array}{c}\mathrm{Ni} \\
{[\mathrm{mg} / \mathrm{kg}]}\end{array}$ & $\begin{array}{c}\mathrm{Cu} \\
{[\mathrm{mg} / \mathrm{kg}]}\end{array}$ & $\begin{array}{c}\mathrm{Mn} \\
{[\mathrm{g} / \mathrm{kg}]}\end{array}$ & $\begin{array}{c}\mathrm{Fe} \\
{[\mathrm{g} / \mathrm{kg}]}\end{array}$ & $\begin{array}{c}\mathrm{Sr} \\
{[\mathrm{mg} / \mathrm{kg}]}\end{array}$ \\
\hline $\mathrm{C}_{\mathrm{i}, \min -\mathrm{C}_{\mathrm{i}, a y}} \mathrm{C}_{\mathrm{i}, \max }$ & $\begin{array}{c}16.1-113.5 \\
42.7\end{array}$ & $\begin{array}{c}22.2-72.5 \\
38.2\end{array}$ & $\begin{array}{c}7.3-12.7 \\
9.5\end{array}$ & $\begin{array}{c}6.6-15.3 \\
9.8\end{array}$ & $\begin{array}{c}0.4-2.5 \\
1.3\end{array}$ & $\begin{array}{c}6.9-15.1 \\
10.0\end{array}$ & $\begin{array}{c}20.9-296.4 \\
88.2\end{array}$ \\
\hline $\begin{array}{l}\text { Background } \\
\text { (Luta 2018) }\end{array}$ & 40 & 40 & 20 & 28 & 500 & - & 400 \\
\hline $\mathrm{K}_{\mathrm{c}, \min }-\mathrm{K}_{\mathrm{c}, \max }$ & $\begin{array}{c}0.4-2.84 \\
1.07\end{array}$ & $\begin{array}{c}0.55-1.81 \\
0.95\end{array}$ & $\begin{array}{c}0.36-0.63 \\
0.47\end{array}$ & $\begin{array}{c}0.24-0.55 \\
0.35\end{array}$ & $\begin{array}{c}0.84-5.04 \\
2.58\end{array}$ & - & $\begin{array}{c}0.05-0.74 \\
0.22\end{array}$ \\
\hline
\end{tabular}




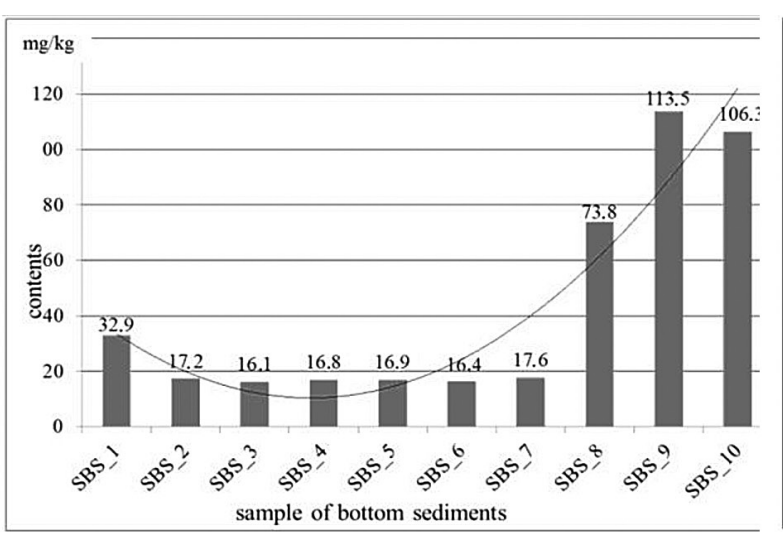

a) $\mathrm{Cr}$

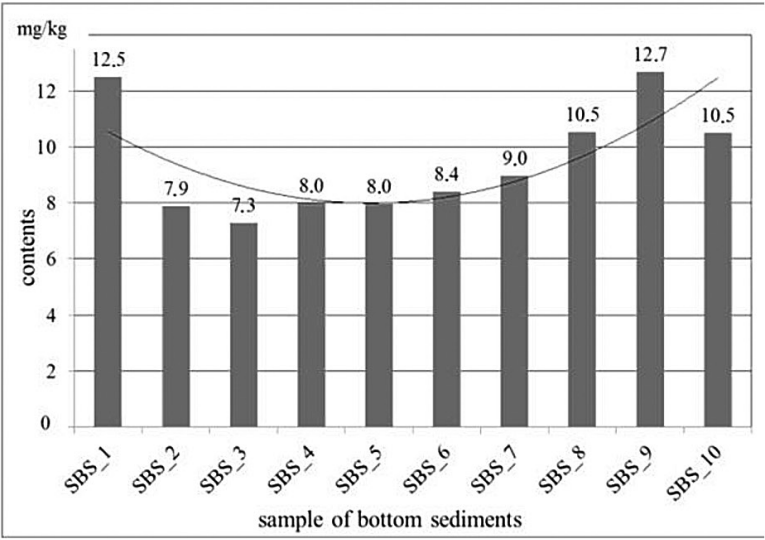

c) $\mathrm{Ni}$

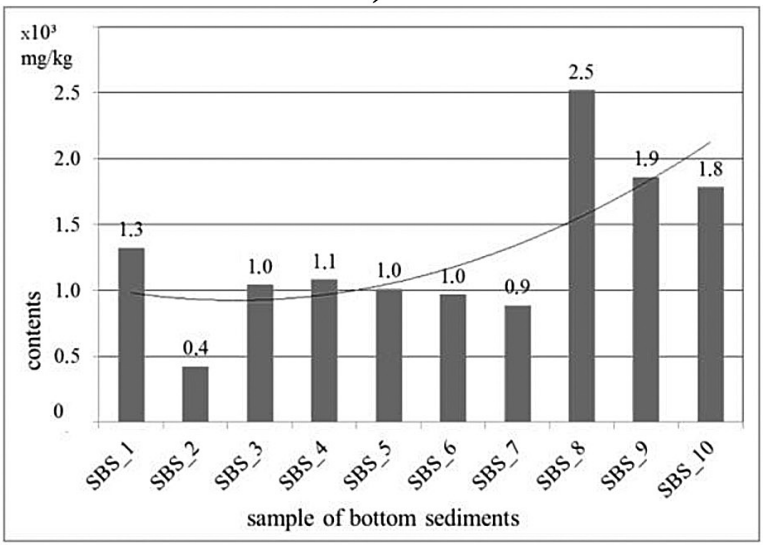

e) $\mathrm{Mn} \times 10^{-3}$

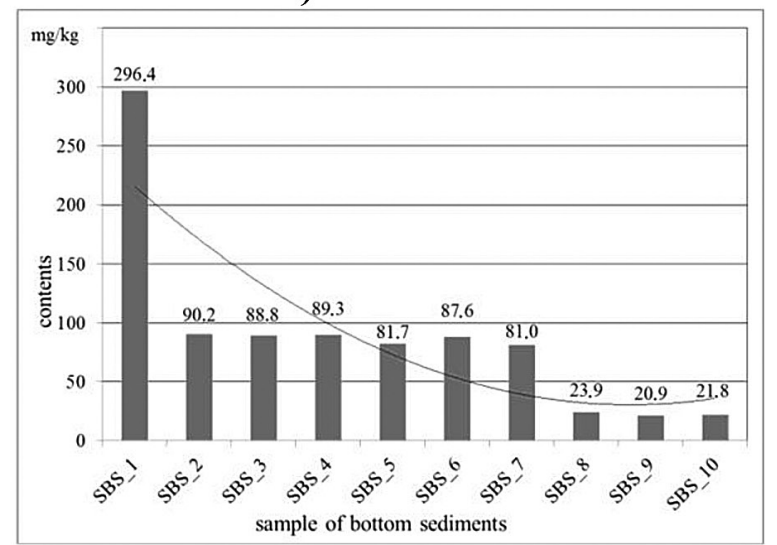

g) $\mathbf{S r}$

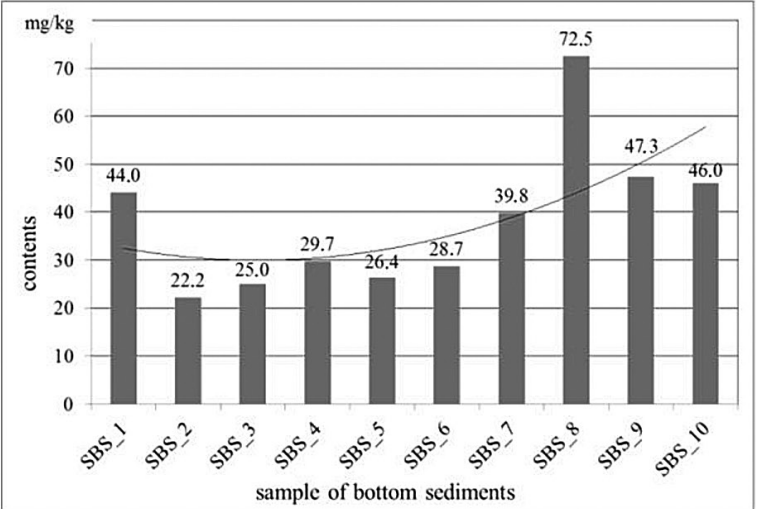

b) $\mathbf{Z n}$

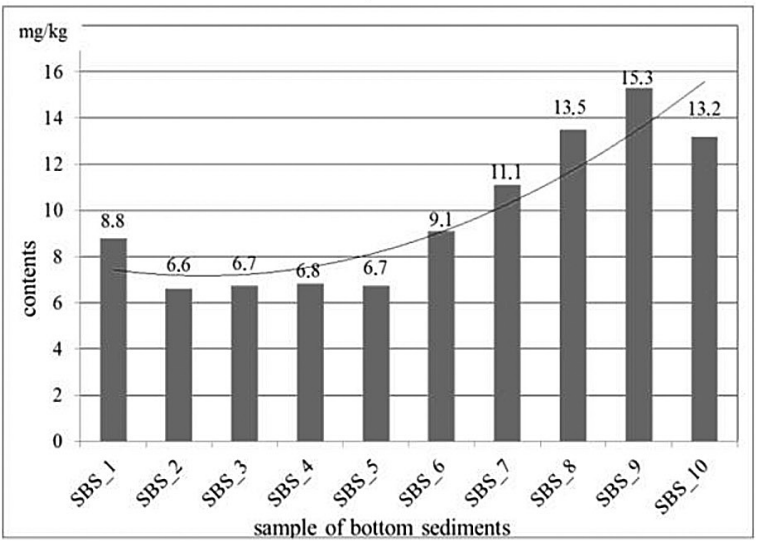

d) $\mathrm{Cu}$

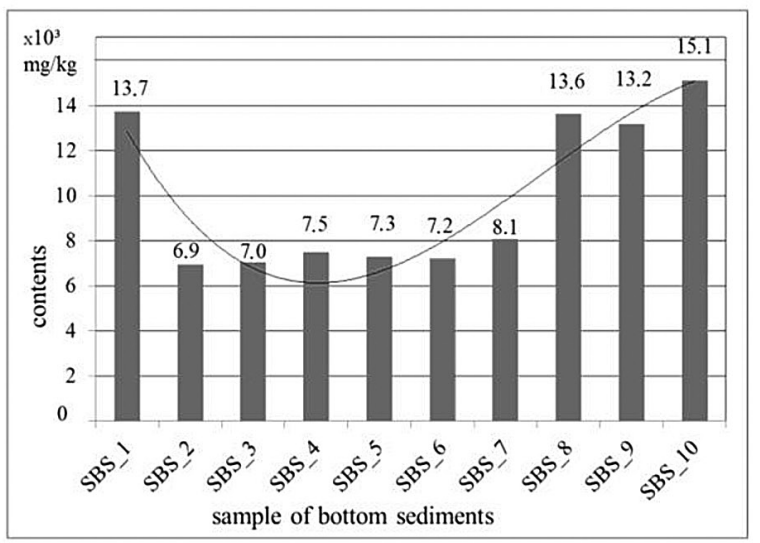

f) $\mathrm{Fe} \times 10^{-3}$

Fig. 2. The content of heavy metals in the bottom sediments of the Southern Bug hydroecosystem. 
are located much lower than the discharge of sewage, for example, at a distance of $50 \mathrm{~km}$.

The analysis of literature proves the toxic effect of excessive concentrations (with excess of background) of nickel and its compounds on hydrobionts. Thus, nickel chloride in the concentration of $4.5-10.0 \mathrm{mg} / \mathrm{l}$ causes the death of mirror carp (Cyprinus Carpio) 200 hours later, on rainbow trout (Parasalmo penshinensis) at a concentration of $25.0 \mathrm{mg} / \mathrm{l}$ and on a gold lynx (Tinca tinca) at a concentration of $55.0 \mathrm{mg} / \mathrm{l}$. The hydrobiont which is most sensitive to the toxic effect of the nickel is daphnia common (Daphnia pulex) in $1.9 \mathrm{mg} / \mathrm{l})$ (Zelikoff 1998, Zelikoff et al. 2002).

The average lethal concentrations of nickel are for freshwater invertebrates (Crustaceae) 0.13-15.2 mg/1 (24-504 hours), for crustaceans (Crustacea) - $6.74 \mathrm{mg} / \mathrm{g}$ (96 hours) (BruckaJastrzbska and Protasowicki 2005).

An algae mikroregma (Mikroregma) and intestinal bacillus (Escherichia coli) hydrobionts are the most sensitive to the nickel chloride. The concentration from $0.1 \mathrm{mg} / \mathrm{l}$ of nickel chloride causes their death. Particular resistance to nickel sulfate is shown by the bristle fish three-pointed (Gasterosleus aculeatus). The death of individuals is observed after 60 hours at a concentration of nickel sulfate $50 \mathrm{mg} / \mathrm{dm}^{3}$ (Lukyanenko 1989).

Copper $(\mathrm{Cu})$ is a chemical element with atomic number 29. In natural waters, the $\mathrm{Cu}$ (II) compounds are encountered most commonly. Out of the $\mathrm{Cu}(\mathrm{I})$ compounds, the least water soluble are $\mathrm{Cu}_{2} \mathrm{O}, \mathrm{Cu}_{2} \mathrm{~S}, \mathrm{CuCl}$. In the reservoirs for fishing purposes, the content of $\mathrm{Cu}$ limitation is based on the toxicological sign of harm to hydrobionts $(\mathrm{MPC}=0.0005 \mathrm{mg} / \mathrm{l})($ Dritsa 1985).

The physiological value of $\mathrm{Cu}$ is due to the content of more than 50 proteins and enzymes in which it is found. In the blood of most mollusks and arthropods, copper is used instead of iron for the transport of oxygen, copper is contained in blood in the plasma proteins of ceruloplasmins, promotes the growth and development of hydrobionts, participates in hematopoiesis, immune responses and is part of the liver proteins (Lukyanenko 1989, Dudnyk 2014, Myslyva 2016).

The content of copper in the investigated area varied in the range from to $6.6-15.3 \mathrm{mg} / \mathrm{kg}$, the average rate was $9.8 \mathrm{mg} / \mathrm{kg}$. Kc was defined within $0.24-0.55$. The average of the index was 0.35 . At the sites of the v. Trikhati - v. Kostyantynivka (SBS_2-SBS_5) the concentration was determined at the level of $6.6-6.8 \mathrm{mg} / \mathrm{kg}$,
$\mathrm{Kc}=0.24$. Twice higher contents of $\mathrm{Cu}$, which ranged from 9.1 to $15.3 \mathrm{mg} / \mathrm{kg}$, were determined at the v. Kiryakivka - River port (SBS_6-SBS_9) (Table 1, Fig. 2d).

\section{Elements of the III class of danger}

Iron $(\mathrm{Fe})$ is the fourth most common element (after O, Si and Al ) in the Earth's crust (Dritsa 1985). There are 308 minerals containing iron, almost 200 of which are formed in hypogeneous conditions in the Earth's crust. The most of natural compounds of iron are oxygen compounds, in the first place among which there are silicates (amphiboles, pyroxenes, mica). Consequently, given the prevalence of this element in the natural environment, the norms of its content in soils have not yet been proposed. Therefore, our assessment was to describe the fluctuations of this element in the bottom sediments of Southern Bug hydroecosystem.

At the study area, the $\mathrm{Kc}$ value varied from 7.0 to $15.0 \mathrm{~g} / \mathrm{kg}$, the average was $10 \mathrm{~g} / \mathrm{kg}$. A clear increase $\mathrm{Fe}$ content was observed in the area of Nova Odesa city (SBS_1) and Mykolaiv city (SBS_8-SBS_10). The Fe content was 13.7 and $13.2-15.1 \mathrm{~g} / \mathrm{kg}$, respectively. At the sites SBS_2-SBS_7, the content of the Fe varied from 7.0 to $8.0 \mathrm{~g} / \mathrm{kg}$, which we consider as background. The maximum concentration of $\mathrm{Fe}(15.1 \mathrm{~g} / \mathrm{kg})$ was observed in the Sea Port area, next to which is the ship building plant, the production activity of which is more than 100 years (Table 1, Fig. 2f).

Manganese is a chemical element with atomic number 25. In the Earth's crust, the Mn content corresponds to about $0.1 \%$ of mass. In seawater, there is about $1.0 \cdot 10^{-8} \%$ of Mn (Trakhtenberg et al. 1994). Most of it is in the form of poorly soluble compounds. The hydrobiont plants assimilate only bivalent manganese. Therefore, the degree of security and the level of its assimilation are closely related from interaction the between water and bottom sediments.

In the study area, the Mn content varied within the range of $0.4-2.5 \mathrm{~g} / \mathrm{kg}$, the average value was $1.3 \mathrm{~g} / \mathrm{kg}$. Accordingly Kc was determined within the range of $0.84-5.0$ with an average of the index of 2.58 .

The space distribution of $\mathrm{Mn}$ in the bottom sediments, was conventionally classified in three zones: (i) wastewaters of the Nova Odesa city treatment facilities carry out technogenic loading of manganese compounds 
to the Southern Bug hydroecosystem. Near Kovalivka, an increased content of manganese to $1.35 \mathrm{~g} / \mathrm{kg}$ (SBS_1) which was recorded that is in three times greater than the content near the v. Tryhaty where the concentration was $0.42 \mathrm{~g} / \mathrm{kg}$ (SBS_2) (Fig. 2e). Accordingly, Kc was 2.64 and 0.84 . According to scientists (Saet et al. 1990), the double exceeding of the background caused an increased level of technogenic load of the bottom sediments, but the natural compensatory processes of dilution due to flow of water were triggered. (ii) The geochemical background at the area (SBS_3-SBS_7) was stabilized at the level of $0.9-1.1 \mathrm{~g} / \mathrm{kg}$. This area is strongly overgrown with with yellow lavender (Latin Núphar lútea), a perennial aquatic plant which is capable of concentrating the $\mathrm{Mn}$ compounds. Perhaps, the process of decomposition of plant remains has led to fluctuations Kc (1.77-2.16). (iii) The third zone was localized on the area (SBS_8-SBS_10). The area of Varvarovka district (SBS_8) was characterized by an abnormally level of manganese in the bottom sediments to $3 \mathrm{~g} / \mathrm{kg}$, which exceeds $\mathrm{Kc}$ in 5 times. This should be explained by the confluence of the Ingul River nearby the Southern Bug. The Ingul hydroecosystem suffers from the dumping of mine waters in the development of manganese ores. However, near the River and Sea ports, the manganese content was stabilized about $1.9 \mathrm{~g} / \mathrm{kg}$, which was the result of natural breeding and sets $\mathrm{Kc}$ in the range of 3.57-3.72.

This element easily diffuses in the water column from the bottom sediments, which is why its migration substantially affects the state of the hydroecosystem. According to the study (Watanabe et al. 1997), manganese is able to enter the fish organism through the gills and intestines, and the level of absorption from the water is quite high. The biological role of manganese is realized through the enzymes that are triggered by this trace element and activate the protein-carbohydrate metabolism, affecting the process of phosphoric-calcium metabolism.

This element, as the enzymes cofactor, also regulates the lipid metabolism, which catalyzes the transformation of mevalonic acid into squalene (a triterpene hydrocarbon series), and stimulates the synthesis of cholesterol and fatty acids in the liver (Watanabe et al. 1997).

Thus, destabilization of background fluctuations can have a significant effect on the functional processes of hydrobionts.
Strontium ( $\mathrm{Sr}$ ) is a chemical element with atomic number 38 . This element is similar to calcium and barium, occupying an intermediate position between them. The average mass of the strontium content is $3.4 \cdot 10^{-2} \%$. It is almost always presents in calcium, potassium and barium minerals. This element weakly reacts with water, forming strontium hydroxide $\mathrm{Sr}(\mathrm{OH})_{2}$ (Dritsa 1985).

In the investigated area, natural strontium was washed out from calcium minerals, which reach the surface in the fault zone of the Ukrainian shield. The Sr content in the bottom sediments varied from 20.9 to $296 \mathrm{mg} / \mathrm{kg}$, the average was $88.2 \mathrm{mg} / \mathrm{kg}$. Kc was defined with range from 0.05 to 0.74 , average 0.22 . The high concentration of $\mathrm{Sr}$ was measured around Nova Odessa and was $300 \mathrm{mg} / \mathrm{kg}$ (SBS_1), Kc was determined at the level of 0.74 (Fig. $2 \mathrm{~g}$ ).

The specifics of the Sr distribution in the investigated section of the hydroecosystem of the Southern Bug consisted in the gradual reduction of its concentration up to $22 \mathrm{mg} / \mathrm{kg}$ in the area of the Seaport of the Mykolaiv city (SBS _10). Perhaps, this is due to the processes of adsorption Sr by such plants as (Latin Nuphar luteum) and common reed (Latin Phragmites australis). Our conclusion was influenced by the results of the research where the studied processes of ${ }^{137} \mathrm{Cs}$ and ${ }^{90} \mathrm{Sr}$ accumulation by higher aquatic plants occurred in the reservoirs of urbanized areas (Watanabe et al. 1997). It is generally thought that strontium does not play a significant biological role, and excessive levels of natural fluctuations in natural waters pose a danger to hydrobionts.

\section{CONCLUSIONS}

The urban areas (Nova Odesa and Mykolaiv) are the sources of the arrival of heavy metals of technogenic origin in the hydroecosystem of the Southern Bug with their subsequent accumulation in the bottom sediments.

Within the limits of the influence of the Mykolaiv industrial and urban agglomeration, geochemical anomalies have been formed with an excess of the regional background for the elements $\mathrm{Cr}$ (2.7-2.9) and $\mathrm{Mn}$ (3.6-5.0). In Kovalivka which is located below the city of Nova Odesa a manganese geochemical anomaly has also generated at the level 2.6. Overall, the average $\mathrm{K}_{\mathrm{c}}$ value is represented as a decrease line: 
$\mathrm{Mn}(2.58)>\mathrm{Cr}(1.1)>\mathrm{Zn}(0.95)>\mathrm{Ni}(0.47)>\mathrm{Cu}$ $(0.35)>\operatorname{Sr}(0.22)$.

By indicator $\mathrm{C}_{\mathrm{i}, \mathrm{av}}(\mathrm{mg} / \mathrm{kg})$ a decrease line was formed: $\mathrm{Fe}(9956)>\mathrm{Mn}(1290)>\mathrm{Sr}(88)>$ $\mathrm{Cr}(43)>\mathrm{Zn}(38)>\mathrm{Ni}(9.5)>\mathrm{Cu}(10)$.

On the area from v. Trikhati to v. Nadbuzske hydroecosystem of the Southern Bug fully activates compensatory mechanisms for the stabilization of natural levels of heavy metals due to current flow, dilution, adsorption by hydrobionts etc., which are represented by the average index $\mathrm{K}_{\mathrm{c}}$ in a decrease line: $\mathrm{Mn}(1.8)>\mathrm{Zn}(0.72)>\mathrm{Cr}(0.42)>$ $\mathrm{Ni}(0.40)>\mathrm{Cu}(0.28)>\mathrm{Sr}(0.22)$.

Technogenic pollutions of bottom sediments with heavy metals affect the qualitative state of the water environment and can cause cumulative toxicosis on the hydrobionts population in zones of geochemical anomalies formation, namely in the area of influence of the Nova Odessa and Mykolaiv cities. The mechanism of the emergence of cumulative toxicosis is accompanied by chronic effects of low concentrations on hydrobionts with an excess of permissible fluctuations on a regional background, which ultimately provokes the development of intoxication. In this case, the immunological resistance of hydrobionts is a significant bioindicator of pollution of the hydroelectric system Southern Bug.

The results of the content of heavy metals research in the sediments are a basis for the development of practical recommendations for dredging, can be recommended as a basis for expanding the monitoring system and the introduction of system observations, and can be used to develop a system of measures to improve the environmental situation.

Today's current economic situation in Ukraine has caused an increase of the population's interest in increasing the diet due to gifts of nature, in particular fish. However, the quality of such products, which is not controlled by anyone, remains unknown; therefore, it is not only a source of additional food resources, but also a carcinogenic risk factor for the population, which is understood as the frequency of neoplasms. Therefore, the question remains open and requires further research.

Moreover, the problem of the complex study of the state of the hydrogeosystem, as a polyfunctional system, is a matter of urgency. In this case, further research should be aimed at modeling and geoinformation representation of the assessment of the state of the hydrogeological system in order to ensure its environmental sustainability.

\section{REFERENCES}

1. Andrusishin G., Grubinko V. 2012. Seasonal Dynamics of Metal Content in Water and Bottom Sediments of the Zbruch River, Visnyk of Lviv University, The biological series, 58, 165-174. Access mode: http://prima.lnu.edu.ua/faculty/biologh/ wis/58/3/18/18.pdf (in Ukrainian).

2. Bandman A., Volkova N., Grekhova T., et al. 1989. Harmful Chemicals. Inorganic Compounds of VVIII Groups: Ref. ed., L.: Chemistry, pp. 592 (in Russian).

3. Bezsonov Y., Mitryasova O., Smyrnov V., Smyrnova S. 2017. Influence of the South-Ukraine electric power producing complex on the ecological condition of the Southern Bug River, Eastern-European Journal of Enterprise Technologies, 4/10 (88), 20-28.

4. Brucka-Jastrzbska E., Protasowicki M. 2005. Effects of Cadmium and Nickel Exposure on Haematological Parameters of Common Carp, Cyprinus carpio L., Acta Ichthyol. Piscat, 35(1), 29-38.

5. Dmitriev M., Kaznina N., Pinigina I. 1989. Sanitarychemical Analysis of Pollutants in the Environment, M.: Chemistry, pp. 368 (in Russian).

6. Dritsa M. 1985. Properties of Elements: Ref. Ed., Metallurgy, pp. 672 pp. Access mode: http:// www.vixri.ru/d2/Drica\%20M.E._SVOJSTVA $\% 20$ ELEMENTOV(spravochnik).pdf (in Russian).

7. Dudnyk S. 2014. Water Toxicology: Method. manual, Part 1. Common Basics of Water Toxicology, National University of Life and Environmental Sciences of Ukraine, K.: Phytocenter, pp. 180 (in Ukrainian).

8. Khilchevsky V. 2009. Water Resources and Quality of River Basins of the Southern Bug River Basin: Monograph [Electronic resource]: Nikacenter, pp. 184. Access mode: [file://D:/-=\%203/ REP0000615\%20(1).PDF] (in Ukrainian).

9. Klebanov D., Osadcha N. 2012. Estimation of Removal of Heavy Metal Compounds by the Waters of the Douni River in the Modern Period, Scientific Papers of the Ukrainian Research Hydrometeorological Institute, 263, 131-151. Access mode: http://nbuv.gov.ua/UJRN/Npundgi 2012 26311 (in Ukrainian).

10. Klymenko M., Zalesky I., Biedunkova O. 2016. Spatial Distribution of Qualitative Characteristics of Heavy Metals Content in the Bottom Sediments of the Usty River, Bulletin of the National University of Water Management and Nature Management, Agricultural sciences, 3, 71-81. Access mode: http://nbuv.gov.ua/UJRN/Vnuvgp_sg_2016_3_7 (in Ukrainian).

11. Koszelnik P., Bartoszek L. 2018. Influence of Sedimentary Fe and Mn on the Oxygenation of Overlying Waters in Dam Reservoirs, Journal of Ecological 
Engineering, 19(5), 180-185.

12. Lukyanenko V. 1989. Fish Immunobiology. Congenital immunity, M.: Agropromizdat, 271 (in Russian).

13. Luta N. 2018. Features of the Distribution of Heavy Metals in the Bottom Sediments of the Rivers of Ukraine, Mineral Resources of Ukraine, 1, 28-32. Access mode: http://nbuv.gov.ua/UJRN/ Mru_2018_1_6(in Ukrainian).

14. Myslyva T. 2016. Heavy Metals and Microelements in Organs and Tissues of their Representatives in the Fauna of the Small Rivers of Zhytomyr Polissya, Bulletin of the Zhytomyr National Agroecological University, (1), 22-34. Access mode: http://nbuv.gov. ua/UJRN/Vzhnau_2016_1(1)_5 (in Ukrainian).

15. Organizing and Conducting Observations on the Content of Pollutants in the Bottom Sediments of Water Bodies: RD 52.24.609-2013. Introduced 02.09.2013 (in Russian).

16. Ostrovsky V., Ostrovsky L. 1998. Guidelines for the Compilation of Geological and Ecological Maps of 1: 200000 - 1: 100000 Scale, M.: VSEGINGEO, pp. 36 (in Russian).

17. Pohrebennyk V., Koszelnik P., Mitryasova O., Dzhumelia E., Zdeb M. 2019. Environmental Monitoring of Soils of Post Industrial Mining Areas, Journal of Ecological Engineering, 20(9), 53-61.

18. Pinkina T. 2006. Influence of Heavy Metal Ions of the Aquatic Environment on the Growth, Propagation and Development of a lagoon (Mollusca, Pulmonata): author's abstract. dis for the sciences. Degree Candidate Biology Sciences: special 03.00.17 Hydrobiology, K., pp. 23 (in Ukrainian).

19. Saet Yu., Revich B., Yanin E., et al. 1990. Environmental Geochemistry, M.: Nedra, pp. 335 (in Russian).

20. Smyrnov V., Smyrnova S. 2014. Spatial Interpolation of Pollution of Bottom Sediments of the Bug estuary by Heavy Metals, Scientific Bulletin of Sukhomlynsky Mykolaiv University, Series: Biological Sciences, 63, 97-102. - Access mode: http://nbuv. gov.ua/UJRN/nvmduc_2014_6(in Ukrainian).

21. Snitinsky V. Sologub L., Antonyak G., et al. 1999. The Biological Role of Chrome in Humans and Animals. Ukr. Biochemistry Journal, 71(2), 5-10 (in Ukrainian).

22. Sukharev S. 2015. Determination of Some Heavy Metals in the Bottom Sediments of the Borzhava River by Atomic Absorption Spectroscopy, Scientific Bulletin of Uzhgorod University, Series: Chemistry, 1, 45-49. Access mode: http://nbuv.gov.ua/ UJRN/Nvuuchem_2015_1_12

23. Trakhtenberg I., Kolesnikov V., Lukovenko V. 1994. Heavy Metals in the Environment: Modern Hygiene and Environmental Aspects, Minsk: Navuka and Technology, pp. 285 (in Russian).

24. Vincent J. 2000. The Biochemistry of Chrome. J. Nutr., 130(4), 715-718.

25. Vytavna Y. Y., Reshetchenko A. I., Dyadin D. V. 2015. Heavy metals in bottom sediments of urban and regional systems nasin $r$. Siverskyy Donets, The municipal economy of the cities, ser.: Technical sciences and architects, 120, 59-63 - Access mode: http://nbuv.gov.ua/UJRN/kgm_tech_2015_120_14 (in Ukrainian).

26. Watanabe T., Kiron V., Satoh H. 1997. Trace Minerals in Fish Nutrition, Aquaculture, 151(1), 185-207.

27. Zelikoff J. 1998. Biomarkers of Immunotoxicity in Fish and Other Non-mammalian Sentinel Species: Predictive Value for Mammals, Toxicology, 129(1), 63-71.

28. Zelikoff J., Carlson E., Li Y., Raymond A., et al. 2002. Immunotoxicity Biomarkers in Fish: Development, Validation and Application for Field Studies and Risk Assessment, Human and Ecological Risk Assessment, 8(2), 253-263. 